\title{
DETECTION OF STREPTOMYCIN RESIDUES IN SHEEP CARCASSES IN DUHOK PROVINCE, KURDISTAN REGION, IRAQ
}

\author{
Shereen Ahmed Yousif Ahmed ${ }^{1}$ and Dhyaa Mohammad Taher Jwher ${ }^{2 *}$ \\ ${ }^{1}$ General directorate of Veterinary, Duhok, Iraq. \\ ${ }^{2}$ Department of Veterinary Public Health, College of Veterinary Medicine, University of Mosul, Mosul, Iraq. \\ * Corresponding author: Dhyaa Mohammad Taher Jwher; email: Deea@GMX.us
}

\begin{abstract}
In general, the Iraqi farmers of breeding and fattening of sheep using a broadspectrum antibiotics like tetracycline and aminoglycosides family for treatment and prophylaxis without considering to the withdrawal periods of these drugs before slaughtering the animals. The aim of the present study was to determine the residues of streptomycin (member of aminoglycosides group) in sheep meat and edible tissues using enzyme linked immunosorbent assay (ELISA) method. A total of 88 samples including longissimus dorsi, diaphragmatic muscles, liver and kidney were collected from 22 sheep carcasses slaughtered in Duhok abattoir, Kurdistan, Iraq. The result revealed that streptomycin residues were found in 12 samples $(54.5 \%)$ of the sheep carcasses distributed as following $36.36 \%, 45.45 \%, 22.72 \%$ and $50 \%$ of Longissimus dorsi, diaphragm muscle, liver and kidney samples., respectively. The minimal streptomycin concentration in ovine meat samples was $3.001 \mathrm{ppb}$ and the maximum concentration was $690.307 \mathrm{ppb}$. The results of this study show that sheep meat, which is sold in Dohuk governorate, often contains the residues of antibiotics due to slaughtered animals might have been treated with veterinary drugs and the proper withdrawal period was not respected before slaughtering.
\end{abstract}

Original Article:

https://dx.doi.org/10.21608/jav $\underline{\underline{s .2019 .62654}}$

Received 03 August, 2019. Accepted 18 September,2019. Published in October, 2019.

This is an open access article under the term of the Creative Commons Attribution 4.0 (CCBY) International License . To view a copy of this license, visit http://creativecommons.org/licen $\underline{\text { ses} / \mathrm{by} / 4.0 /}$

Keywords: Abattoir, Duhok , ELISA, . Sheep Carcasses, Streptomycin residues

\section{INTRODUCTION}

Meat is one of the most important constituents of human diet as it provides proteins, energy, minerals and several B vitamins (Bender, 1992). Livestock production is growing rapidly as a result of the increasing demand for animal products (FAO, 2002). World population is projected to increase to 7.7 billion by the year 2020 . Thus, demand forfood protein of animal origin is expected to increase more rapidly than total population (Lineback et al., 1999).Today, antibiotics play a major role in modern agriculture andlivestock industries, and their use has been on the rise in many developed nations. One of the major uses of antibiotics in recent years is to enhance growth and feed efficiency in healthy livestock (Sarmah $\boldsymbol{e t}$ al., 2006).

Currently, approximately $80 \%$ of all foodproducing animals receive medication for part or most of their lives. The most commonly used antimicrobials in food producing animals are the $\beta$-Lactames, aminoglycosides , macrolides, sulfonamides and lincosamides ( Lee et al., 2001). Veterinary drugs, especially antibiotics are important, not only as beneficial compounds for animal health and animal welfare but as risks as well, being potential sources of residues in food of animal origin, when after administration of veterinary medicines to the animals the withdrawal time in relation to the maximum residue limit (MRL) is not taken into account (Vaarkamp, 2002).

The occurrence of these residues may be due to many reasons however the most important of these factors, from the tissue residue's point of view, is lack of commitment to the prescribed withdrawal period of the drug before the animal is sent to market for human consumption (Akinwumi et al., $2012 \mathrm{~s}$ include direct toxic effects on consumers like allergic reactions and indirect problems through induction of resistant strains of pathogenic bacteria (Dubois et al., 2001).

Residues from these antibiotics may be present in edible tissues, milk and eggs and may exert different levels of toxicity on consumers when consuming them. Thus, easy, rapid and sensitive tests are really needed for an effective at line use (Toldra and Reig, 2006). At present, there are various methods for detection of antibiotic residues which might be present in food of animal origin which can be classified to 
Microbiological, Instrumental and Immunoassay methods (Abdullah et al., 2012).

Streptomycin antibiotic is an member of aminoglycoside family, which is usually used in veterinary medicine as the sulfate salt. It is has been used to treat bacterial diseases in cattle, pigs, sheep and poultry. The recommended therapeutic doses range from 5 to $10 \mathrm{mg} / \mathrm{kg}$ bw/day for 3 to 5 days by the parenteral route or from 25 to $100 \mathrm{mg} / \mathrm{kg}$ bw/day for 3 to 5 days via the drinking water. Ototoxicity and nephrotoxicity are reported extremely. Nephrotoxicity bring much attention since it may result in renal failure due to acute tubular necrosis with secondary interstitial damage, Persistence of streptomycin in plasma and thus urine is likely to predispose the tubular cells to toxicity (Martinez-Salgado, et al., 2007; Selimoglu, 2007).

Analysis of veterinary drug residues in animal products has been developing prominently in the last years and it appears to be a new trend from the aspect of food safety. This development has been moving towards finding quicker and more sensitive screening methods for the detection of residues and more sophisticated methods for the confirmation of non-compliant samples obtained by screening tests (Clanjak et al., 2011)

Due to the lack of awareness regarding antibiotic residues in food of animal origin and its impacts on consumers and lack of exact data in the region about the rate of these substances, this study has been carried out and it is the first reported confirmatory and quantitative analysis of streptomycin residue in animal products in Duhok province- Kurdistanregion.

The aim of this study is detecting of streptomycin residues in sheep meat and various edible tissues intended for human consumption by using ELISA Technique.

\section{MATERIALS AND METHODS}

Eighty eight samples have been collected from 22 sheep carcasseswhich were slaughtered within one week of August 2013 in Duhokabattoir to analyze for streptomycin residue using competitive enzyme linked immunoassay (Shenzhen Lvshiyuan Biotechnology Co.,Ltd, China). Four samples of: Longismus dorsi, diaphragmatic muscle, liver and kidneys were taken from each carcass. Each sample $200 \mathrm{~g}$ was packed in a clean plastic bag and given an identifying number then transported immediately to the Faculty of Veterinary Medicine- Vet. Public Health laboratory in an ice box with a minimum period of delay to be prepared for the test. Samples were stored at $-20^{\circ} \mathrm{C}$. The values of ELISA have compared with the Maximum residue limits (MRL) according to European Medicines Agency, Veterinary Medicines and Inspections, EMEA/CVMP/463923/2006-Final December 2006

RESULTS

Out of 22 sheep carcasses inspected, streptomycin residues were observed in the following percentages of $45.45 \%, 50 \%, 27.27 \%$ and $54.54 \%$ in Longissimus dorsi muscle, diaphragm, liver and kidney, respectively The mean concentration of streptomycin residues in the inspected samples are presented in Table (1).

\begin{tabular}{|c|c|c|c|c|c|}
\hline \multirow{2}{*}{$\begin{array}{l}\text { Sample } \\
\text { no. }\end{array}$} & \multicolumn{4}{|c|}{ Streptomycin residue (ppb) } & \multirow[b]{2}{*}{ MRLs* } \\
\hline & $\begin{array}{l}\text { Longissimus } \\
\text { dorsi muscle }\end{array}$ & $\begin{array}{l}\text { diaphragm } \\
\text { muscle }\end{array}$ & Liver & Kidney & \\
\hline 1 & 5.005 & 39.962 & 00.00 & 20.005 & acceptable \\
\hline 2 & 00.00 & 00.00 & 00.00 & 581.030 & Not acceptable \\
\hline 3 & 34.351 & 690.307 & 35.601 & 489.901 & Not acceptable \\
\hline 4 & 159.993 & 581.030 & 00.00 & 433.871 & Not acceptable \\
\hline 5 & 082.183 & 581.030 & 065.801 & 581.030 & Not acceptable \\
\hline 8 & 03.672 & 584.667 & 584.667 & 143.600 & Not acceptable \\
\hline 11 & 00.00 & 00.00 & 690.307 & 70.870 & Not acceptable \\
\hline 12 & 690.307 & 149.656 & 690.307 & 690.307 & Not acceptable \\
\hline 13 & 690.307 & 00.00 & 00.00 & 00.00 & Not acceptable \\
\hline 15 & 00.00 & 00.00 & 00.00 & 671.578 & Not acceptable \\
\hline 16 & 00.00 & 690.307 & 00.00 & 690.307 & Not acceptable \\
\hline 18 & 22.183 & 580.214 & 00.00 & 580.331 & Not acceptable \\
\hline 19 & 580.249 & 672.113 & 00.00 & 00.00 & Not acceptable \\
\hline 20 & 00.00 & 486.288 & 00.00 & 496.288 & acceptable \\
\hline 21 & 3.672 & 00.00 & 3.001 & 00.00 & acceptable \\
\hline 22 & 00.00 & 077.031 & 00.00 & 00.00 & acceptable \\
\hline
\end{tabular}

$*=$ MRLs according to European Medicines Agency Veterinary Medicines and Inspections, EMEA/CVMP/463923/2006-Final December 2006 
As shown in Table 2, the concentrations of streptomycin were ranged between $3.672-690.307$ for Longissimus dorsi muscle, 39.962 - 695.307 for diaphragm, 3.001- 690.307 for liver and 20.005- 698.307 for kidneys

Table 2: Mean of residual streptomycin (ppb) detected in mutton (Longissimus dorsi m., diaphragm m., Liver and Kidney) samples.

\begin{tabular}{|l|c|c|c|c|}
\hline \multicolumn{1}{|c|}{ samples } & $\begin{array}{c}\text { No. of Positive } \\
\text { samples }\end{array}$ & $\begin{array}{c}\text { Range of STR. } \\
\text { conc. } \mathrm{ppb}\end{array}$ & $\begin{array}{c}\text { Mean } \\
(\mathrm{ppb})\end{array}$ & $\begin{array}{c}\text { Positive } \\
\%\end{array}$ \\
\hline Longissimus dorsi $m$. & 10 & $3.672-690.307$ & 247.6872 & 45.45 \\
\hline diaphragm $m$. & 11 & $39.962-695.307$ & 246.7779 & 50 \\
\hline Liver & 6 & $3.001-690.307$ & 230.8611 & 27.27 \\
\hline Kidney & 12 & $20.005-698.307$ & 217.9091 & 54.54 \\
\hline
\end{tabular}

\section{DISCUSSION}

Meat is regarded as an essential feedstuff for human beings due to its high nutritional value, digestibility and palatability. Meat contains good quality proteins representing a major source of many nutritional elements and minerals such as vitamins, iron and zinc.

In Iraq, cattle including sheep represent the main source of animal protein serving as important food-producing animals for both Iraqi and Kurdistan region people. However, the demand for animal products increases annually in correspondence to the increase of population. Consequently, many animal raisers expanded their scale of livestock production in a horizontal scope to meet the demand for animal products and to increase their profitable business (Ifft, 2005). The concentration of large numbers of animals in large production units and the need to avoid and treat disease outbreaks has led producers to use antibiotics indiscriminately and apply "Blanket treatment" for these animals (FAO, 2009).

In Iraq, the classic habit followed in which animal breeders administer a wide spectrum of veterinary drugs randomly to their animals without observing the withdrawal periods of these drugs before they are slaughtered for human consumption. Supplementation of antibiotics to feedstuffs to promote growth rate and increase weight gain is another habit applied by farmers for the sake of obtaining maximal profitability with the least period of breeding These drugs, in turn, accumulate in animal's tissues and products as residues.

Application of antibiotics randomly is widely followed by farmers even without veterinary diagnosis and supervision in most cases. Eventually, slaughtering is the fate of sick animals which do not respond to antibiotic treatment. Some animals included in this study showed certain pathological lesions, They might be treated by veterinary pharmaceuticals prior slaughtering without respect to withdrawal time. Table
$(1,2)$ showed the percentage of samples containing streptomycin residues. The mean value of streptomycin residue in Longissimus dorsi samples was $277.19 \mathrm{ppb}$ and ranged between $690.307 \mathrm{ppb}$ and $3.672 \mathrm{ppb}$. While the maximum residue level in diaphragmatic muscle samples was 690.30ppb and minimum level of 39.96 $\mathrm{ppb}$ with the mean value of $466.60 \mathrm{ppb}$. The table also showed that $47.6 \%$ of positive samples of longissimus dorsi and diaphragm contained residue levels over the MRL (500) ppb as per EU standards for muscles (EC, 2010).

Residual streptomycin levels ppb of liver samples ranged between 690.30 and $3.001 \mathrm{ppb}$ with the mean of $344.94 \mathrm{ppb}$, and $50 \%$ of positive liver samples were over the MRL (500 ppb) as per EU standards for liver (EC, 2010). Residues of streptomycin were present in kidney samples and ranged between 20.005 and $690.30 \mathrm{ppb}$ with the mean value of $454.09 \mathrm{ppb}$ which is below the MRL (1000 ppb) as per (EU) standards for kidney, and $100 \%$ of kidney samples were below the MRL (1000 ppb) as per EU standards for kidney $(\mathbf{E C}, \mathbf{2 0 1 0})$. The presence of these antibiotics in high percentage may be due to the availability of these antibiotics in markets with low cost promoted their broad administration.

Generally, it is obvious that high rates of residues in various animal tissues and products are reported in developing countries in contrast to what is found in the developed world according to the European Community findings. Such reports revealed that positive samples for 57 antibiotic residues in food of animal origin were less than $1 \%$, exactly $0.19 \%$ (EC, 2013), which could be attributed to the type of animal husbandry, management and production system. Consequently, in developing countries a greater proportion of animal breeding is done by uncultivated herdsmen who always purchase veterinary drugs over the counter for administration to their animals without a veterinary diagnosis, prescription and supervision. Unfortunately, this condition is an indication of lack of 
public health regulatory control in developing countries.

\section{CONCLUSION}

The results of this study show that sheep meat, which is sold in Dohuk governorate, often contains the residues of antibiotics due to slaughtered animals might have been treated with veterinary drugs and the proper withdrawal period was not respected before slaughtering. Although, these levels are within the acceptable limits but their presence in meat may cause health risks represented by allergic reactions and development of antibacterial resistance to antibiotics, So all actions must be taken to reduce antibiotic residues in meat should be applied through education by veterinary personnel, rapid screening procedures for the analysis of antibiotic residues and prohibition of meat containing antibiotics more than MRL.

\section{Declaration of Competing interest}

On behalf of all authors, I hereby declare that no conflict of interest may interfere with the publication of the manuscript.

\section{REFERENCES}

ADAMS, H. R.2001. Veterinary Pharmacology and Therapeutics, A Blackwell Publishing Company, 8th edition, 2001, Iowa State press, USA. Pp. 818828.

AKINWUMI, A. O., OLATOYE, I. O., ODUNSI, A. A., OMOJOLA, A. B., AND RAFIU, T. A.2012. Effects of Antibiotic Residue on the Physical Qualities of Beef in Oyo State, Nigeria, 4th International Conference on Agriculture and Animal Science, Singapore.

ABDULlAH, O. A., SHAREEF, A. M. AND SHEET, O. H.2012. Detection of streptomycin residues in local meat of bovine and ovine. Iraqi Journal of Veterinary Sciences, 26(1): (43-46).

BENDER, A. 1992. Meat and Meat Products in Human Nutrition in Developing Countries. Food and Nutrition paper No. 53. Rome, FAO.

CLANJAK, E., SMAJLOVIC, M., CAKLOVICA, F., ALAGIC, D., CAKLOVICA,K.,SMAJLOVIC, A.2011. Detection of enrofloxacin residues in chicken meat by microbiological (growth inhibition test) and ELISA method after experimental prophylactic and therapeutic application. MESO Journal, Croatia, 13(3):198. Online, http://hrcak.srce.hr/file/108059.

DUBOIS, M., FLUCHARD, D., SIOR, E. AND DELAHAUT, PH. 2001. Identification and quantification of five macrolide antibiotics in several tissues, eggs and milk by liquid chromatography-electrospray tandem mass spectrometry, Journal of Chromatography B. 753:189-202.

EC. 2013. European Community Report for 2011 on the results from the monitoring of veterinary medicinal product residues and other substances in live animals and animal products, European Food Safety
Authority (EFSA), Parma, Italy. Online: www.efsa.europa.eu /publications.

EC. 2010. Commission Regulation No $37 / 2010$ of 22 December 2009 on pharmacologically active substances and their classification regarding maximum residue limits in foodstuffs of animal origin, official Journal of EC. Available online http://ec.europa.eu/health/files/eudralex/vol 5/reg_2010_37/reg_2010_37_en.pdf.

FAO. 2009. The State of Food and Agriculture, Livestock in the Balance, Rome. http://www.fao.org/ fileadmin/user_upload/animal welfare/SOFAe.

FAO. 2002. Protein Sources for the Animal Feed Industry. Animal Production and Health, Food and Agriculture Organization of the United Nations. Available www.fao.org/docrep/007/y5019e/y5019e07.htm

IFFT, J. 2005. Survey of the East Asia Livestock Sector, Rural Development and Natural Resources Sector Unit of the East Asia and Pacific Region of the World Bank, Working Paper. http://go.worldbank.org/32ZO2UBPK0.

LEE, H. J., LEE, M. H. AND RUY, P. D. 2001a. Public Health Risks: Chemicals and Antibiotic Residues, Suwon, Korea. Asian - Australasian Journal of Animal Sciences, 14(3): 402-413.

LINEBACK, D. R., STUCKEY, R. E. AND NIYO, K. A. 1999. Animal Agriculture and Global Food Supply, Council for Agriculture Science and Technology, Task Force Report No. 135, USA, available at http://agrienvarchive.ca/ bioenergy/download/anag.

MARTINEZ-SALGADO C, LOPEZ-HERNANDEZ FJ, AND LOPEZ-NOVOA JM. 2007. Glomerular nephrotoxicity of aminoglycosides. Toxicology and Applied Pharmacology, 223: 86-98.

SELIMOGLU E.2007. Aminoglycoside-induced ototoxicity. Current Pharmaceutical Design, 13(1):119-126.

SARMAH, A. K., MEYER, M. T. AND BOXALL, A. B. 2006. A global perspective on the use, sales, exposure pathways, occurrence, fate and effects of veterinary antibiotics (VAs) in the environment. Chemosphere, 65: 725-759.

TOLDRÁ, F. AND REIG, M.2006. Methods for rapid detection of chemical and veterinary drug residues in animal foods. Elsevier Ltd., Trends in Food Science \& Technology 17: 482-489.

VAARKAMP, H. 2002. Maximum residue levels (MRL's) of veterinary medicines in relation to food safety. MRL's really do matter - the Benzaprocpen case. Tijdschr Diergeneeskd, 127(1):2-6.

How to cite this article:

Shereen Ahmed Yousif Ahmed and Dhyaa Mohammad Taher Jwher, 2019. Detection of Streptomycin Residues in Sheep Carcasses In Duhok Province, Kurdistan Region, Iraq. Journal of Applied Veterinary Sciences, 4(2): 41-44.

DOI : https://dx.doi.org/10.21608/javs.2019.62654 